\title{
JAZZ RESEARCH AND THE MOMENTS OF CHANGE
}

The motivation to write this article comes from my personal experience, which has shown that jazz research as a distinct academic discipline tends to be relatively little known in scholarly circles, remaining beyond the field of jazz studies itself. In introducing the field, my study has no ambitions to provide a comprehensive overview of the discipline. Rather than scrutinize the detail or theoretical and methodological questions or provide a survey of the entire historiography, I will primarily focus on meta-level discussions - discussions of the historical dynamics of the growth of the discipline as constructed and debated over the last 25 years. Based on a critical reading of selected scholarly texts, the study highlights two turning points in the history of the jazz studies field, which I consider here as the two moments where jazz research underwent extensive changes, expanding the field's qualitative grasp and geographical scope. Because of limitations of space, my point of interest is predominantly jazz research as a written intellectual form of scholarship, and less as institutional pedagogical practices as in jazz education programmes. The America-centric perspective in the selection of the texts, especially in the first section of the study, reflects the American origin of my jazz educational background and encounters with American society and ethos. The wish to define my own identity as a researcher has encouraged me to look beyond dominant Americanized perspectives and to embrace a more broadly integrated unity of the field. 
The first moment - professionalization or academization - is understood here as a discursive shift in the field when the critical study of jazz became a part of the American academic establishment in the late 1980s and early 1990s. Concurrently with the questioning of canon formation in many academic fields and the emergence of the New Musicology movement the New Jazz Studies appeared as a field of research examining critically previous jazz historiographies. The works of scholars like Krin Gabbard (1995a; 1995b), Scott DeVeaux (1991) and John Gennari (1991) generated the transformations that deconstructed established master narratives and implied the growth of new strategies of investigation ranging from approaches to jazz as a musical phenomenon, to various models scrutinizing jazz as culture.

According to Sherry Tucker (2005) the shift toward New Jazz Studies took place in 1988, with the first appearance of the first jazz panel at the Modern Language Association. Featuring Krin Gabbard, Mike Jarrett, William Kenney, and Kathy Ogren, this panel helped to launch a watershed moment of New Jazz Studies publishing, with three anthologies: Jazz in Mind: Essays on the History and Meanings of Jazz (Buckner \& Weiland 1991), Jazz Among the Discourses (Gabbard 1995a), and Representing Jazz in (Gabbard 1995b). The mid-1990 also saw the founding of interdisciplinary jazz studies conferences, such as Leeds International Jazz Conference and Guelph Jazz Festival and Colloquium, both inaugurated in 1994 (Tucker 2005).

The two issues I will concentrate on during my discussion of the academization of jazz studies field are the disciplinary status of jazz research and the critique of jazz studies' canon-formation. The study of those issues is largely based on what can be called the canonized writings of Scott DeVeaux and Krin Gabbard.

The second moment of change - the globalization of the American centered field of academic jazz studies - is a process which I think is still in progress. The symbolic beginning of the shift towards broader perspectives can be marked by the publishing of the first scholarly collection of articles on jazz beyond American borders called Jazz Planet by Taylor Atkins in 2003. As a scholar working on jazz history in a non-American context, my point of interest is the dynamic between American centered NJs and non-American jazz discourse. This section of three chapters tries to analyse the reasons for the split within jazz's scholarly discourse, and to discover the paths of writing in national settings. The final 
chapter, as an illustration of my discussions of jazz studies in the national context, briefly introduces the current state of the discipline in Finland. The relevance of the inclusion of this topic also reflects the Finnish origin of the current anthology. In addition, the reference to the Finnish case is also intended here to strengthen one of the arguments of this chapter: that the attentions of jazz scholarship have increasingly broadened to recognize what had hitherto been thought of as the 'unimportant margins'.

\section{Calls for professionalization}

One of the foreshadowings of the imminent change in jazz studies was Lewis Porter's 1988 essay Some problems in jazz research. The author - known as jazz pianist, musicologist and founder of the world's first jazz history program (the Master's Program in Jazz History and Research at Rutgers University Newark) - associates the change in the field with institutional politics in Us academia. The proliferation of academic jazz programs in American Universities and Colleges created a new generation of professional researchers who offered fresh insights into the music by applying rigorous methodological tools to investigate jazz.

Porter's article carries highly critical undertones towards previous writers and writings on jazz. With the statement that "Musical analysis must also take cultural factors in account. It is not necessarily appropriate for jazz researchers to imitate classical models and methods" he commented on the rise of formalist musicology in the style of Schuller where detailed analysis of musical structure and questions of thematic unity were at the center of investigation (Porter 1988: 202). Porter's claims that jazz research should be detached from the formalistic methodologies and approaches to cultural studies, concern the key problems framing the debates within the upcoming New Jazz Studies.

Who is the jazz researcher? The question about the identity of the individual working on jazz from a scholarly perspective was another major topic raised by Porter. Referring to jazz researchers of previous generations who were predominantly discographers and journalists, he laments that most jazz research has been conducted by individuals who were neither musicians nor academics, 
which handicapped them as jazz researchers (1988: 195). That the jazz researcher should rely not only on scholarly and musical knowledge but also on practical experience is still a pre-eminent understanding regarding those engaged with jazz scholarship. As Porter claimed, "Jazz scholars should be versed in a variety of research methods, should know music, and, ideally, should be performers" (1988: 204).

A year later Scott DeVeaux complained about the amateurish nature of jazz research and its flourishing outside the walls of academia until late 1980s. Jazz study was rooted in the lively trade and specialty magazines that since the $1930 \mathrm{~s}$ have served the interests of the aficionados - a term, as journalist Frederick Turner (as cited in DeVeaux 1989: 1) has noted, "in our language is reserved for devotees of bullfighting and jazz, both presumably odd passions". Most of the writers have made their way as freelance critics and journalists. This practice has given to their work an unpretentiousness and independence of spirit that roughly parallels that of the music itself. It has also encouraged a certain insularity that, unfortunately, has made jazz a difficult subject for an outsider to approach (DeVeaux 1989: 1).

\section{Where do jazz studies belong?}

DeVeaux was probably one of the first persons to initiate discussion about the disciplinary status of jazz research. As he claimed, jazz is a suitable subject for both musicology and ethnomusicology, but in practice it tends to fall between the two. The reason for that is the inadequacy of musicologists' knowledge of jazz, leaving them uncomfortable with the field. The traditional methods of musicological research are difficult to apply to jazz - to the music characterized by reliance on improvisation, in which the written score is displaced by the recorded performance as the primary source, and the boundary between composer and performer is fluid. Jazz was also unable to attract the attention of American ethnomusicologists, who supposedly were more experienced with oral traditions and better equipped to handle jazz issues. As mentioned by DeVeaux (1989: 2), jazz articles have been virtually absent from the pages of Ethnomusicology, the Society's journal. 
The controversial relationship between jazz and musicology is an emerging topic also in the context of two of jazz studies' landmark volumes Jazz Among the Discourses (JAD), and Representing Jazz (RJ). That those volumes expanded remarkably the disciplinary territory of jazz studies is announced by the editor Krin Gabbard (1995a: 22) in the introduction to JAD: "The essays in this volume strongly argue that jazz studies is now being transformed and invigorated by new ideas and approaches". It unquestionably leads us to think that this is the new musicology applied to jazz we see in these volumes, but somewhat odd is the fact that virtually no musicologists or musically trained scholars contributed to Gabbard's enterprise.

As Tucker (1998) says in his article "Musicology and the New Jazz Studies", twenty-two of the twenty-three contributors are affiliated with academic departments other than music, including American studies, Afro-American studies, art history, communication, English and comparative literature, film studies, history, and philosophy. Only Robert Walser is identified as teaching in a university department of music, and only he and Ronald M. Radano received their primary scholarly training in music (Tucker 1998: 133). Why is the profile of musicologists so low? Tucker points out the historical tradition from which jazz studies were descended from as one of the reasons. The writers who helped lay the foundation of jazz studies in 1930s were journalists, enthusiasts, and record collectors, usually with little or no formal music background. In the 1950 os and 1960s the most prominent jazz writers were not products of musicology programs but knowledgeable musicians and critics (Gunther Schuller, Andre Hodeir, Max Harrison, Martin Williams) or free-lance writers pursuing careers outside of music journalism (Ralph Ellison, Albert Murray, Amiri Baraka, Nat Hentoff). Before the mid 1970s the only scholars writing on the subject were Alan P. Merriam and Lawrence Gushee. As Tucker summarizes, the sparse presence of musicologists in Gabbard's collections is not surprising: "It would be extraordinary if a volume of essays on jazz were to appear with contributions only by scholars of music" (Tucker 1998: 133-134).

Robert Walser, in his essay on Miles Davis, faults musicological treatments of jazz for being chiefly devoted to legitimation. Additional problems with musicological approaches to jazz as cited by Walser are the adoption of narrow, exclusionary definitions of the music, the uncritical use of sources - recordings and 
oral histories - and the disregard of social and historical particularities behind music making (Walser 1995). The problems of jazz scholarship have been examined also by Bruce Johnson. He demonstrates how the focus on jazz recordings and the application of formalist musicology denied the importance of orality/ aurality in jazz (Johnson 1993).

The other appropriate disciplinary host for jazz research seems to be popular music studies. Jazz shares a common past with popular music, and meets the criteria for the definition of popular music according to Frith. Like popular music, jazz is made commercially, it uses ever-changing technology, it is often experienced as mediated, it is made for pleasure and is formally hybrid bringing together large number of musical elements (Frith 2007: 8-9). But somewhat paradoxical is the fact that jazz has not been a welcome guest in popular music studies either. Jazz and popular music as scholarly fields have remained a rarely overlapping research and teaching areas.

One reason why jazz and popular music have been separated as academic fields is provided by Simon Frith in his 2007 essay Is Jazz Popular Music. It was jazz scholars' low interest towards popular music studies which caused the separation or as Frith (2007: 11) expresses rhetorically: "Jazz scholars had no interest in playing on it!". As in relation of jazz with musicology, this again raises the issue of jazz studies' non-professional journalistic practice based on the past and journalists' resistance to academic theories. Jazz researchers were looking for insights into musicians rather than into listeners, and were uninterested in cultural studies shaping popular music research.

On the other hand, the dominant body of jazz teachers in the academy were instrumental teachers rather than theorists. The aim of the most prominent jazz organization The International Association of Jazz Educators, IAJE, founded in late 1960s America, was to ensure the development of jazz, and considering the concurrent growing invasion of rock in popular music, to protect jazz from the threat of rock. Thus, the question is first of all why popular music as defined by scholars does not include jazz, but why the jazz world doesn't regard jazz as a part of popular music (Frith 2007: 13). Here I need to reformulate also my previous statement on the unwillingness of popular music studies to host jazz. As we have seen, it is other way around: jazz studies itself has been uninterested in locating itself in the field of popular music studies. 
Frith's argumentation, however, is mainly based on the examples originating from the pre-professional period in jazz studies in the past. With the emergence of a new generation of professional researchers and the application of wide variety of new methodological tools to investigate jazz, the rigorous disciplinary borderlines between jazz and popular music seem to have been blurred. We have seen several scholars like Robert Walser, Johan Fornäs and Bruce Johnson stepping freely back and forth between the two fields, and popular music's most prestigious journal Popular Music not hesitating to publish jazz related writings. What I think is a remarkable sign of 'popularizing' jazz studies is the recently (2011) published anthology Jazz in a series of The Library of Essays on Popular Music which main editor is Allan F. Moore. As the editor of the collection Tony Whyton confidently states in the opening of the volume, "Jazz has always been at the heart of popular music discourse. Despite continued detachment of the term 'jazz' and 'popular music' in pedagogical and research terms, jazz has not only provided one of the central foundations in popular music studies but has also continued to play a complex and integral role in the workings of popular culture" (2011: xi). What still seems to be the main separating factor between jazz and popular music studies is the domination of monolithic and parochial American jazz discourses in jazz studies which are not in tune with the fragmented and global nature of popular music studies.

\section{Jazz canon and its critique}

The writing with the most significant impact on canon and canon formation in jazz studies is Krin Gabbard's introductory essay The Jazz Canon and Its Consequences in JAD. Gabbard contends that the major tendency of jazz scholarship has been the uncritical canonization of jazz artists. The canonization of jazz - or more precisely, the canonization of certain artists and styles - is for Gabbard (1995a: 2) inescapable "if the music is to claim its place within the academy". The existence of a well established canon is also a prerequisite for new developments and change for one scholarly discipline. By making reference to debates within film studies that offer instructive models for the institutionalization of jazz, Gabbard 
points out that in film studies "the current deconstruction of cinematic texts by film theorists might not have become so prominent without canonizing discourse to oppose" (1995: 6). And he seems to be impatient to force change in jazz studies. The absence of professional discourse in jazz studies is what he sees as the main obstacle to the growth of the field. As he complains, "if a discipline can be considered 'professionalized' when it develops its own metalanguage and selfconsciousness about its canon, then jazz studies is still in its infancy" (Gabbard 1995a: 11).

Thus, Gabbard's manifesto for a New Jazz Studies relies on two arguments. One is the notion of professionalizing the field of jazz studies. Gabbard explains the process of creating a metalanguage and a series of methodologies that exclude the amateur. "Anyone can engage in evaluation and express an opinion about a book, a play or a film," he claims, but "only a professional can speak a language and brandish a paradigm understood only by a coterie of specialists with mastery over the same language and paradigm" (1995a: 7). Almost everyone who has written about jazz for the last eighty years belongs to what Gabbard terms the discipline's 'pre-professional' phase. The NJs, instead, demand that scholars develop "a professional discourse that may at first draw on the vocabularies of musicology, sociology, critical theory and other disciplines but that ultimately will be unique to jazz studies" (1995a: 7).

Another argument in Gabbard's agenda is the thesis about the discipline's self-consciousness about its canon. Although the canonization of jazz artists has almost always been the major thrust of jazz scholarship, its scholars need to be more self-conscious about the problematic nature of canon formation even as they continue to write about the key artists of the discipline. The engine driving canon-formation is, for Gabbard, ideology. Although he acknowledged the importance of ideology he, however, ignores his statement while approaching the course of previous jazz studies. The high voltage of criticism towards the canonizers and their uncritical canonization of jazz artists of the preprofessional era - the discographers, and writers like Gunther Schuller and Martin Williams disregards the fact that these figures who studied jazz certainly operated according to different ideological agendas (Tucker 1998: 147). The aim of those writers legitimating jazz by 'classicizing' it was first all to build a canon of jazz based on the jazz tradition and contemporary ideologies. 
Considering the heatedness of Gabbard's criticism against the recently constructed jazz canon I would like to ask a somewhat ethical question in the spirit of DeVeaux (1991: 553): Isn't it little unfair to deconstruct a canonical view of jazz history so soon after it has been constructed? But the process of deconstructing the previous canon is as inevitable as the formation of the new one. The canon changes constantly because historical circumstances and stimuli change and people therefore approach it in myriad ways, bringing different perspectives and needs to it, reading it in ways distinctive to the times in which they live, and emerging with different satisfactions and revelations (Levine 1997: 93).

The essay which I regard as the most influential writing in jazz studies is Scott DeVeaux's 'Constructing the Jazz Tradition' (1991). The importance of the writing relies on initiating the self-reflective and critical approach to historiography in jazz. By describing how an 'official' history of jazz drawing on narratives of organic growth and stylistic progression emerged, DeVeaux refers to the ideological implications of canon formation lying behind this representation. The importance of DeVeaux's essay is excellently articulated by Sherry Tucker who underlines the eye-opening effect of the writing: "'Constructing the Jazz Tradition' provided an important analytic power that helped me and other jazz scholars to understand why certain artists, musics, and histories had been overshadowed, why straight line of one genius/one style leading to another prevailed as a dominant narrative. It helped us to hear other jazz histories, approaches, analyses, voices, perspectives, and questions" (2005: 33).

Several authors have linked the problems of the jazz canon directly to the conventions of academic history courses and the jazz textbooks for college and university (see DeVeaux 1991; Prouty 2010; Tomlinson 2002). As DeVeaux (1991) claims, those textbooks represent in an excellent way the established canonical narratives of jazz and have great impact on shaping the views of students and teachers of jazz history. Tomlinson criticizes the extensive reliance of textbooks on Martin Williams' collection of musical samples Smithsonian Collection of Classic Jazz. But this reliance is one of convenience. As he states pragmatically, "recordings need to be easily available for students" (Tomlinson 2002: 88). Mark C. Gridley's influential and (most) widely used course book Jazz Styles: History and Analysis (first edition in 1985) can be criticized, apart from its language, for representing only a musical history of jazz without paying any attention to the social 
and historical context of the music. A volume, which I believe satisfies both criteria - analysing the music excellently and telling the story of jazz - is Giddins's and DeVeaux's (2009) recent history book called Jazz.

\section{Black canon}

The jazz canon was not challenged only by a growing academic white establishment of jazz scholarship but also by an emerging wave of black writers. By launching the debates on jazz and its racial origins they questioned the ownership of the jazz canon. There is no space here to discuss the whole complexity of the relationship between jazz and race related issues. But briefly, the connection between jazz and its 'skincolour' has been interpreted by those close to jazz musicians, critics or fans - broadly in two different ways. There have been those who hold the race-neutral view by stating that jazz had become a lingua franca, and as such, was better described as 'interracial' and not constrained by racial boundaries. At the other edge of the spectrum are those who regard connections with jazz and black culture from an essentialist perspective and insist on its remaining the cultural property of African-Americans (Horn 2002).

The discussions of blackness in jazz in general terms were not new when Imamu Amiri Baraka, known also as LeRoi Jones, published Blues People in 1963. But prior to that time the topic was mainly the property of white jazz journalists. By arguing that jazz is essentially the music of African Americans and that an underlying racial message pervades every sound of the music, he launched an Afrocentrist attack on the American white establishment that has owned and exploited the music for forty years (Brown 2004).

The figure whose efforts are the most frequently associated with a canonformation in black American discourse is literary scholar Henry Louis Gates. Besides his credentials as a founder of Black American literary canon-formation, he was also valued for changing the rules of canon-formation. According to Gabbard (1995a), the inclusion of a sound recording with the Norton Anthology of African American Literature (NAAAL), featuring readings of poetry, novels, and the like, emphasizes the oral and performative dimensions of much of black literature. But Black American literary canon-formation and the NAAAL have crit- 
ics also. Tomlinson (2002) sees the ambivalence at the Gates's project of forming a black literary canon. According to him, Gates sees the need for a wholesale redefinition of canonic thought, but at the same time he pushes forward a project of old-fashioned white, male, European canon building. The solution to Gates's dilemma is not to abandon altogether notions of canon but to redefine the concept of an institution of literature. In making personal canons the scholars should not empower the existing shared and metapersonal canons by uniting with their ideological establishment but, instead, move toward a personal dialogic mode of evaluation. As Tomlinson stated:

What we need is not to construct more institutions but instead to deinstitutionalize the canons we have, to strip away the structures of power in which they are enmeshed and reveal them as the congeries of personal choices they are. We need, in other words, to turn our attention from the self-bolstering search for personal canons similar to our own to the less comforting scrutiny of and dialogue with canons divergent from ours (Tomlinson 2002: 84).

Gates's most significant contribution to African-American literary theory is his concept of signifyin (g) presented in The Signifying Monkey: A Theory of African-American Literary Criticism (1988). Built on principles and theories which come from a vernacular black American tradition of signifyin(g), called by Tomlinson also as an African-American mode of what Bakhtin called dialogism, Gates emphasizes the performative dimensions of black literature (Tomlinson 2002: 73). As Gates (1988: $53,88)$ himself has said, signifyin(g) is "...a way of saying one thing and meaning another; it is a reinterpretation, a metaphor for the revision for the previous texts and figures; it is tropological thought, repetition with difference, the obscuring of meaning". Musical signifyin(g), as a successful Afrocentric perspective moving beyond the standard approaches of musicology and ethnomusicology, has been a widely used analytical category in jazz studies (see for instance by Floyd 1995, 1991; Walser 1995; Monson 1994; Tomlinson 1991). It provides a means for discourse on musical performance, referring to the rhetorical use of the musical tropes subsumed under the master trope of Call-Response: calls cries, whoops, hollers; call-and-response, elisions, pendular and blue thirds, musical expressions, vocal imitations of instruments, multimeter, cross-rhythms, and interlocking rhythms. 
Musical signifyin(g) carries with it a non-lexical expressive value, a telling effect that asserts, quests, requests, implies, mocks, groans, concurs, and signifies misgivings and suspicions (Floyd 1991: 271-272). As Gates (1988: 63) himself has suggested, the jazz tradition is essentially a signifyin(g) tradition: "There are so many examples of signifyin(g) in jazz that one could write a formal history of its development on this basis alone". In response, Tomlinson (Tomlinson 2002: 88) claims that Jazz Signification is largely extra-canonic since much of the jazz musician's Signification has played on musical works and styles from outside the jazz critics' mainstream.

Another influential black canon-builder has been Wynton Marsalis with his Jazz at Lincoln Center enterprise and his collaborators Stanley Crouch and Albert Murray. We indeed can thank Marsalis for his attempts to preserve the American jazz tradition but it was achieved at the expense of rigorous exclusionism and formation of a narrow black essentialist canon. As writers criticizing Marsalis have rightly mentioned, his neoclassicist attitude is an attempt to regulate the music of the present through an idealized representation of the past; his objection to free jazz and fusion is a sign of the narrowness of his narrative and disregard for music's groundbreaking changes; and his notion of 'jazz-as-classical music' is too evidently flirting with classical music and its canon (Brown 2004). Nowhere is the exclusionary tightness of Marsalis's narrative more apparent than in the documentary on jazz, produced by American film maker Ken Burns, in which Marsalis played a role of main adviser and major contributor. The debate prompted by the documentary blamed its authors for presenting the old 'great-black-geniuses' type of history while leaving white musicians out of the picture. Burns's story marginalized the avant-garde strands of the music particularly since 1960, and it characterized the fusion movement as a move towards a debasing commercialism.

The brief mapping of the role of NJs in the discourse of jazz leads to the conclusion that its greatest achievement has been the professionalization of jazz research. The initiation of the dialogue with other disciplines of the humanities and the expansion of the disciplinary boundaries of the field was the agency for jazz's liberation from its status as an independent scholarly subject. In spite of those substantial changes, we can still see the American jazz canon standing like an impregnable fortress in the heart of jazz studies' discourse. In Tony Whyton's words, 
Although the New Jazz Studies has stressed that culture is a dynamic entity, and has therefore employed a range of methodological tools to investigate jazz history as a complex and contested discourse, the presence of an authoritative jazz canon remains an attractive monolithic construct within the jazz mainstream, impacting on the study and performance of jazz in academic and professional settings (Whyton 2011: xv).

\section{Global studies and controversies}

The first extensive collection of articles to leave the dominating American-centered discourse out of focus and to detail the spread of jazz into cultures outside American boundaries was Jazz Planet (2003) by E. Taylor Atkins. In an opening essay 'Toward the Global History of Jazz' Atkins blames jazz studies for utilizing parochial methods and dismissing jazz within the narrative of globalization. The narrative of this music has been told predominantly from an American perspective and represents jazz as a distinctively American cultural phenomenon speaking with a unique American voice. As Atkins (2003: xiii) asserted, "Practically all jazz discourse rests on the premise of American exceptionalism, the dogmatic conviction that democracy, individualism and social mobility, civil society, free enterprise, ingenuity, and inventiveness, and material wellbeing are peculiarly American traits".

Although jazz is a phenomenon of American origin, which could only have emerged in the American cultural context, it was a part of wider early-twentieth century social, cultural and political processes. Jazz as one of the early 2oth century global trends was first received, then adopted and finally practiced by musicians of diverse nationalities all over the world since its very inception. But the music was not received homogeneously: during the acculturation process jazz, by being in open dialogue with different traditions, was appropriated to local cultural contexts - via the process that has often been called glocalization (Reimann 2011: 24).

The question immediately arising here is about the politics of the relationship between American and non-American discourse: why jazz, which in its very na- 
ture is a global music, has largely remained beyond the scope of NJs. The reasons for that are manifold. One is definitely an unwillingness on the part of the American jazz community to recognize the global achievements of jazz. Stuart Nicholson (2005: 165) claims in his intriguing Is Jazz Dead? (or has it moved to a new address) that, "as the flow of communication in the global cultural economy becomes even faster, the people who are not discussing the effects on globalization of jazz are Americans[.... many fans are unaware of the impact the music had beyond their shores. Few albums and bands from outside the United States are heard there". The situation is criticized also by Americans themselves. Lewis Porter recognizes the ignorance and low level of interest from the American side to jazz outside us borders:

In my opinion, most Americans are ignorant of jazz outside the UsA. I collect international jazz recordings, and have performed all over Europe, so I know that some of the best jazz musicians are not American. But the New Jazz Studies was a movement started in America and unfortunately there has been little interest in or knowledge about jazz outside the usA. (Personal e-mail correspondence, Porter 11.01.2013.)

This ignorance is partly related to the notion of America-centrism - a term privileging purely American values and ethos. The byproduct of American centrism is, in turn, isolationism where America functions as a society closed to information, facts and opinions of the rest of the world.

Some enlightening reflections on jazz as a subject of academic discourse are made by Bruce Johnson by the example of Australia. Drawing a parallel between the situation in Australian Literature Departments in 196os and current jazz studies, led him to the obvious conclusion that the domination of Anglophone scholarship overshadows the local developments.

When I think about the reasons [why NJs is an American centered field], I recall the situation regarding Australian literature when I was an undergraduate in the 1960s. There were very few courses in Australian literature in Australian Literature Departments until the 1970s, and at the time I used to think this was odd, although the reason was clear: Anglophone scholarship in the field was domi- 
nated by the idea of English Literature, rather than Literature in English, and so the local or 'vernacular' forms were regarded as insufficiently developed or interesting to be worth displacing the English canon.

The situation remained the same in jazz studies until much later. The dominant assumption was that jazz was a us phenomenon, and everything outside was a poor imitation. My position is that the 'poorer' the imitation, the more interesting it is. (Personal e-mail correspondence, Johnson 11.01.2013.)

Although Johnson recognizes that there is more and more interest in diasporic jazz, however, "the shadow of cultural colonialism still hangs over jazz studies, most especially at the level of education and cultural policy" (Johnson 2013). This conflict derives from cultural lag. As he says, "while things change at the level of local practice, it takes the discourse (academic, pedagogic, policy) a very long time - at least a generation - to catch up. 'The Street' is always ahead of 'The Academy'" (Johnson 2013). I have made a similar statement about the dynamic between academic discourse and musical scenes in analyzing the situation in jazz pedagogy dominated by American mainstream methodologies. Pedagogy seems to be conservative and inert in its (very) nature: it is slow in reacting to changes and fails to keep up with developments and shifts in society. For me the future of jazz education relies on inclusion rather that in exclusion, in diversity of methodologies rather than in one orthodox or central approach, and in decanonization rather than in canonization (Reimann 2013: 184). I think the latter-mentioned ideas could serve as a good basis for thinking about the jazz studies field as well. Instead of contrasts, insularities and somewhat simplistic binary descriptions dominating the discourse on American/global divide, it is fruitful to approach this binary in terms of intercultural dialogue and celebration of pluralism.

But not only American isolationism and cultural colonialism limit the globalization of jazz studies' discourse. The part of jazz remaining outside American borders has been predominantly studied in national contexts scrutinizing the local particularities of the music in a local cultural context. Even if not speaking in the local language, those studies in any case talk from the local perspectives with little or no reference to American canonized jazz discourse located at the center of NJs. It is then America-centric '(jazz) blindness' on the one hand, and 
the local nationalistic self-defense to preserve cultural identity on the other hand, that has drawn the sharp borderlines between American and non-American jazz discourse. Also the dispersed nature of non-American jazz discourse is another reason for the divide. The language barrier, which is definitely one of the main factors affecting dispersal, limits the wider access to national histories. For instance, access to the large body of work written in German speaking cultural space where jazz studies has a long history and well developed institutional system with jazz centers in Darmstatd and Graz (it has become, since 1969, an international center for jazz research), privileges those speaking the language. In my own recent attempts to set up a history course on European jazz, I was faced with the difficulty of finding comprehensive literature for preparing the lectures. The material had to rely extensively directly from historians with whom I had personal contacts.

However, in today's discourse jazz is more than ever before understood as a practice that has developed through a range of influences and exchange. An excellent illustration is the previously mentioned anthology Jazz where a third section entitled 'Receptions, Scenes, Global' perspectives explores the ways which jazz has functioned in global scenes. "Although the New Jazz Studies could be accused of initially overlooking the presence of jazz outside the USA, in recent years, there has been a growing interest in how jazz feeds into debates on globalization and the Americanization of world culture," says Tony Whyton (2011b: xx) in the introduction. Hopefully the American centered enterprise of New Jazz Studies will be challenged also by the ongoing project Rhythm Changes led by University of Salford. The mission of the 3-year research project is to examine the inherited traditions and practices of European jazz cultures particularly in Danish, Dutch, Norwegian, Austrian and British national contexts. The two successful conferences (Rhythm Changes: Jazz and National Identities, 2011, Amsterdam, and Rhythm Changes II: Rethinking Jazz Cultures, 2013, Salford) provided an opportunity for scholars to explore and present a transnational view of jazz as an exchange of ideas and inspirations.

The two volumes, which I think can be regarded as milestones in recent European jazz studies are the already mentioned Stuart Nicholson's Is Jazz Dead? (or has it moved to a new address) and Eurojazzland - an extensive volume on European jazz edited by Cerchiari, Cugny, and Kerschbaumer. Nicholson's book has 
not only attracted the attention of jazz scholars but has received also significant feedback from the media and jazz community. In discussing the global and glocal impact of jazz, Nicholson describes the way jazz has been received and adapted within global contexts. But his writings do not move beyond a simple inversion of the jazz-as American/jazz as global binary, as Tony Whyton (2012: 370) says. Although, on the surface, Nicholson's work reads as an important challenge to the hegemony of the neo-traditionalist agenda in the United States, actally, it has replaced one form of essentialist narrative with another (Whyton 2012: 370). The collection of essays in the recent Eurojazzland is not dedicated to transnational history but to the complex, broader subject of the relation between Europe and jazz. The reading of Cherchari's introduction leaves no doubt that a comprehensive book on jazz in Europe on which we are waiting, will be effectively written soon.

\section{Writing on jazz in national contexts}

The final issue to discuss is inspired by Bruce Johnson's response to my assumption made during e-mail correspondence that "global or non-American jazz has largely remained beyond the scope of New Jazz Studies". His question 'compared to what?' directed me to the myriad other questions which can be asked here. What are the criteria for one's research to be qualified as NJs? What is the ideological agenda looming behind the identity of somebody who wants to be identified as a new jazz scholar? And finally, will what Johnson calls diasporic jazz be considered as a part of NJs project or shall it remain a private territory for nationally-orientated scholarly establishment?

Rather than trying to answer all these binary-based questions, my orientation here is more conciliating by attempting to trace out mutually acceptable parallels between American and national jazz discourses. As we have seen, the greatest achievement of NJs was to impose new disciplinary parameters on the jazz studies field. The application of a new scholarly metalanguage and new interdisciplinary scholarly perspectives were the most obvious indicators of professionalization of jazz research. The professionalization of the field - its transition from journalistic aficionado dominated discourse to academic scholarly scrutiny - seems to be an issue also beyond American borders. The large body of research 
on jazz's past has been conducted on the basis of Lowenthal's (1998) model of heritage. He correctly argues that we need to make a distinction between history and heritage: while history's goal is the understanding of the past then heritage is a celebration of the past in its continuity. According to this distinction the large body of work on jazz's past - data collection, record collecting, journalism and popular histories - belong rather to the category of heritage than professional historiography. While in heritage writing the data collection is a final stage of the process, in professionalized historiography on the other hand the data collection is just an initial step - the starting point for further investigations.

Take, for instance, the case of jazz history research in Estonia where the collection and preservation of the data have been the main goals in investigating the music's past. Like his American counterparts in the preprofessional period Valter Ojakäär, a man whom Immo Mihkelson called in his radio program Uus heli the 'spokes-person number one in Estonian jazz', was a journalist, musician and discographer whose journalistic activities in different media channels have introduced jazz to Estonian listeners since the end of the 1950s. Ojakäär's biggest contribution to Estonian cultural history is unquestionably his four volume series of books that uncovers the historical legacy of Estonian 'light' or popular music from its very beginning in the first decades of the $20^{\text {th }}$ century to the present-day and is therefore an excellent document based on the memories of the author and his personal contacts with the musicians. Ojakäär's narrative is constructed in a non-linear manner where the central position is held by persons, ensembles and orchestras. In any case, in spite of its stylistic shortcomings - the lack of historical coherence and consistency - the series provides a painstakingly detailed overview of historical data and facts, and therefore serves as an excellent source for further scholarly investigations. The only dissertation on Estonian jazz is Tiit Lauk's Jazz in Estonia in 1918-1945 (2008) the aim of which is to investigate how jazz music reached Estonian cultural space. The value of the work lies more in the collection of data than scholarly analysis of jazz culture.

As mentioned above, although the NJs shook the disciplinary foundations of previous jazz studies, its central assumptions still revolve around the American jazz canon. Therefore, the scholar working on the history of jazz in a national context has two option in writing his/her narratives: whether to ignore the dominating American jazz canon and construct the narrative purely in the context of 
nationality and national history, or to complement the list of their perspectives with canonical American views and narrate the story in a global context. Our understanding of the role of the nation and 'the national' in relation to music and the histories we are making is extensively discussed by Weisethaunet (2007). He makes a distinction between two types of scholars working on national histories. While for some music historians, the 'nation' - and its 'culture' - seems almost a given, then "others are far more reluctant to mythologize the impact of such representations, in the sense that national narratives, as well as our understandings of 'culture' as a homogeneous denominator" (Weisethaunet 2007: 170). Referring to Bhabha and to his claim about the ambivalent nature of modern society, Weisethaunet (2007: 191) emphasizes the importance of perspective as the narrative of the nation is written: "whether it is a celebratory narration; whether it is framed as a response to colonialism; if it is a counter-hegemonic narration; or if it is imagined with a perspective on transnational histories etcetera". That Norwegian jazz history should not be written as one-sided narration solely within national frameworks is unquestionable for Weisethaunet: the discussions on orally disseminated music with international appeal, like jazz, cannot be restricted by single national context or cultural spaces.

Listening to jazz recordings made in Norway in the 1930 and 40 it seems evident that Norwegian musicians were capable of learning from their American mentors in a way that reflects the specific timbral qualities of jazz musicianship of that particular era, however, the reason for this was undoubtedly that jazz was already international, and people had learned aurally from listening to jazz records. In sum, the history of such music cannot be framed within an one-sidedly 'national' perspective. (Weisethaunet 2007: 187.)

And I think Weisethaunet is right in stating that national narratives of jazz should also include a transnational global (American) perspective rather than telling the story solely from a nationalistic single-view position. However, what is necessary to take into account here is the gradually decreasing impact of the American jazz canon. At least until 1950 os the music played in national scenes was with minor exceptions an imitation of American music, but in contemporary global scenes jazz's dependence on its motherland is relatively loose and the American impact 
is accordingly smaller than previously. Therefore, the inclusion of American perspectives seems to be inescapable in narrating the history of jazz, for instance in 1930 Estonia, but perhaps dispensable in discussions of the developments of jazz in 21st century context.

\section{Jazz studies in Finland}

As an illustration of my ruminations on the mode for discussing jazz in the national context, this chapter tries to outline the state of jazz studies in Finland by highlighting some distinctive tendencies in the development of the field.

That jazz as a scholarly subject has a relatively low profile compared to other musical styles in the Finnish context is clearly indicated by the number of dissertations. Only eight researchers have selected jazz as the subject of their theses. In terms of methodological approach the works belong to various disciplines. The author of the first dissertation on jazz was Pekka Jalkanen. His Alaska, Bombay ja Billy boy: Jazzkulttuurin murros Helsingissä 1920-luvulla (1989) is an excellent example of new history writing where the jazz narrative is told in a larger historical and cultural context.

Although Pirkko Moisala (2010: 75) excludes jazz from popular music studies and mentions Jalkanen's work as a founder of Finnish popular music studies, I think, the writing also sounds as an effective opening chord for professional research on jazz in Finland. Written in 1989 it was definitely a step ahead forward from the contemporary jazz writings in America of the time. Jalkanen, however, somewhat problematizes the term jazz itself in the context of Finnish jazz history by suggesting the term rytmimusiikki (rhythmic music) instead. This term, used predominantly in Nordic regions of Europe (for instance rytmisk musik in Danmark, rütmimuusika in Estonia) can be regarded as an umbrella term for the music using rhythm as one of the basic expressive devices. As the rector of Helsinki Pop \& Jazz Conservatory Janne Murto has jokingly said on the webpage of Finnish Suomen Rytmimusiikki 2010 visio: "Rytmimusiikki is music that is not played in a concert hall by wearing a tailcoat". Nevertheless, the notion seems to have established its position in an educational context rather than being deployed in scholarly discussions. 
Subsequent dissertations were based on cognitive musicology (Järvinen 1997), formal musical analysis (Henriksson 1998; Liukko 2012), phenomenology and semiotics (Toivanen 2000; Lemponen 2001), jazz pedagogy (Poutiainen 2009). A remarkable study is Elina Hytönen's (2010) ethnomusicological project on jazz musicians' flow experiences, the originality of which gives it great potential for international success. Among dissertations that have more or less dealt with jazz, there is, for instance, Anu Juva's study on 1950 and 1960 film music "Hollywoodsyndromi", jazzia ja dodekafoniaa (2008).

While Finnish ethnomusicology manifests a low level of interest in cultures beyond its borders (Moisala 2010: 75), jazz researchers, conversely, seem to be more interested in looking abroad than seeking for native subjects. The point is illustrated in the articles in Etnomusikologian vuosikirja series - only two out of ten articles on jazz were dedicated to Finnish jazz.

Besides Jalkanen's work the second extensive scholarly investigation on the history of Finnish jazz is a book project on jazziskelmä (Jazz-Pop Hit Songs) Suklaasydän, tinakuoret: Jazziskelmä Suomessa 1956-1963. The collection discusses jazziskelmä from a large number of perspectives. It introduces the stylistic features of the music, its recordings and performers on the one hand, and analysis the cultural meaning of the style on the other. Although the history of jazz has enjoyed a modest scholarly interest in Finland, however, the music is well documented in the form of non-scholarly history writing. We can find several overviews on jazz's historical past (Haavisto 1991, 1994; Jalkanen \& Kurkela 2001), biographies of individual musicians (Henriksson \& Lindström 2005) and collections of historical recordings (for instance the series Finnish Jazz published by Jazz \& Pop Archive). Olli Häme's Rytmin voittokulku (1949), which provides an outline of the history of jazz and popular music for Finnish readers is also worth mentioning, and as Lemponen (2001: 7) has stated the book has become an important 'bible' for musicians, students, jazz aficionados, fans, and also for researchers.

The current state of affairs within jazz studies in Finland is not, however, exceptional. That a large body of jazz history has been written in popular form and in a native language, that the researchers' interest toward jazz as a cultural, historical and social phenomenon is lower than to jazz as a musical phenomenon, and that it is difficult to identify jazz studies as an independent scholarly field, 
were the issues already more or less pointed out in the course of my study. To decide whether the researchers' low interest in jazz comes from scholarly trends/ politics, from scholars' caution in approaching the music, or from some other reasons is not my goal here. To expect that jazz studies will be another fraktio (referring to Vesa Kurkela's [2005] distinctions in music studies in Finland) in Finnish music studies is probably too optimistic but hopefully more scholars will dare to tangle with the music in the future.

\section{Conclusions}

By mapping the trajectory of the evolution of academic jazz studies, the article outlined two moments in the discipline's history, referred to here as professionalization and globalization. While the first moment entailed changes in the subject's substantive side, the second marked the expansion of its geographical scope.

Although the institutional history of jazz studies remained beyond the focus of the article, as noted in the introduction, it should be mentioned that the need for the institutional legitimation of the discipline became the primary initiator of its growth. The searches for disciplinary status and canonization were both launched by the processes of institutionalization, where entering academia required the subject to be presented in a coherent form acceptable in the academic world. As a written intellectual form of scholarship, jazz studies exists, according to my own argument, in a clearly recognizable mode with its own historical tradition, trans-disciplinary form, meta-language and scholarly journals. But as an institutional practice, the field tends to be relatively less independent. Jazz as an independent object of study is largely practised in research centres and academic programmes on jazz research (Jazz Research in Graz, Jazzinstitut Darmstadt, The Institute of Jazz Studies at Rutgers University, The Center for Jazz Studies at Columbia University), but academic positions in jazz scholarship at university level are still a rarity. The academic community working in the field comprises a wide range of participants from a variety of disciplines - African-American studies, literary studies, cultural studies, sociology, history, film studies, musicology, ethnomusicology, anthropology etc. 
The globalization of jazz research, which was pointed out as the second moment of change in the current study, has been impeded by several factors as my analysis has demonstrated. America-centrism and cultural colonialism, on the one hand, and language barriers and nationally orientated scholarly traditions, on the other, have prevented dialogue between American and non-American jazz studies. Based on my personal observations, the somewhat tense atmosphere has recently, however, noticeably calmer, and both sides are in a process of celebrating the intercultural dialogue and accepting pluralistic views more than ever before.

In response to my questions on the identification of a scholar of New Jazz Studies, I tend to think that a researcher attempting to join the NJS project is nevertheless expected to certain criteria irrespective of his/her affiliation or national origin. A general awareness of the tradition - an acceptance of the discipline's rootedness in American soil, and the distinctive network of references and dialogue within the tradition are features facilitating the process of continuity in the field and define the identity of the New Jazz Studies scholar. 


\section{References}

\section{Email correspondences}

E-mail correspondence with Lewis Porter, 11.01.2013

E-mail correspondence with Bruce Johnson, 11.01.2013

\section{Literature}

Atkins, Taylor E. (2003). “Towards a global history of jazz". Jazz Planet. Ed. Taylor E. Atkins. Mississippi: University Press. Pp. xii-xvii.

Baraka, Amiri (1963) Blues People: Negro Music in White America. New York: Morrow Quill paperbacks.

Brown, Lee (2004) "Marsalis and Baraka: An Essay in Comparative Cultural Discourse Author(s)". Popular Music 23:3, pp. 241-255.

Buckner, Reginald T. \& Weiland, Steven (1991) Jazz in Mind: Essays on the History and Meanings of Jazz. Detroit: Wyne State.

DeVeaux, Scott (1989) “Introduction". American Music (Special Jazz Issue). 7:1, pp. 1-5.

DeVeaux, Scott (1991) "Constructing the Jazz Tradition: Jazz Historiography". Black American Literature Forum, 25:3, pp. 525-560.

Floyd, Samuel A. Jr. (1991) "Ring Shout! Literary Studies, Historical Studies, and Black Music Inquiry". Black Music Research Journal. 11:2, pp. 265-287.

Floyd, Samuel A. Jr. (1995) The Power of Black Music: Interpreting Its History from Africa to the United States. New York: Oxford University Press.

Frith, Simon (2007) "Is jazz popular music? ". Jazz Research Journal. 1, pp. 7-23.

Gabbard, Krin (ed.) (1995a) Jazz Among the Discourses. London: Duke University Press.

Gabbard, Krin (ed.)(1995b) Representing Jazz. London: Duke University Press. Gabbard, Krin (1995c) "Introduction: The Jazz Canon and Its Consequences". Jazz Among the Discourses. Ed. Krin Gabbard. London: Duke University Press. Pp. 1-28.

Gates, Henry Louis (1988) The Signifying Monkey: A Theory of African-American Literary Criticism. New York: Oxford University Press. 
Giddins, Gary \& DeVeaux, Scott (2009) Jazz. Michigan: W. W. Norton \& Company.

Gennari, John (1991) “Jazz Criticism: Its Development And Ideologies". Black American Literature Forum. 25:3, pp. 449-523.

Haavisto, Jukka (1991) Puuvillapelloilta kaskimaille: jatsin ja jazzin vaiheita Suomessa. Helsinki: kustannusosakeyhtiö Otava.

Haavisto, Jukka (1994) Suomijazzin vuosikymmenet: jazzmusiikki Suomessa vuosina 1919-1969. Sibelius-Akatemian koulutusjulkaisuja.

Henriksson, Juha (1998) Chasing the Bird: Functional Harmony in Charlie Parker's Bebop Themes. Acta Musicologica Fennica 21. Helsinki: The Finnish Musicological Society.

Horn, David (2002) "The Identity of Jazz". Cambridge Companion to Jazz. Eds. David Horn \& Mervyn Cook. Cambridge: Cambridge University Press. Pp. 9-32.

Häme, Olli (1949) Rytmin voittokulku: Kirja tanssimusiikista. Helsinki: Fazer.

Hytönen, Elina (2010) Moments of Bliss and Transcendence in Jazz: Professional Jazz Musicians' reports of Flow Experiences. Doctoral dissertation, University of Eastern-Finland.

Jalkanen, Pekka (1989) Alaska, Bombay ja Billy boy: Jazzkulttuurin murros Helsingissä 1920-luvulla. Helsinki: Suomen etnomusikologisen seuran julkaisuja.

Jalkanen, Pekka \& Kurkela, Vesa (2003) Suomen musiikin historia. Populaarimusiikki. Helsinki: wsoy.

Johnson, Bruce (1993) “Hear Me Talkin' To Ya: problems of jazz discourse”, Popular Music' 12/1 (January, 1-12).

Juva, Anu (2008) "Hollywood-syndromi", jazzia ja dodekafoniaa. Åbo Akademi University Press. Järvinen, Topi (1997) Tonal Dynamics and Metrical Structures in Jazz Improvisation. University of Jyväskylä.

Kurkela, Vesa (2005) "Etnomusikologian sukupolvet", Musiikin Suunta, 2, pp. 47-59.

Lemponen, Seppo (2001) Swing to Bop - Hep to Hip. A Study in Jazz Parlance. Jyväskylä: University of Jyväskylä.

Levine, Lawrence W (1997) The Opening of the American Mind: Canons, Culture, and History. Boston: Beacon Press.

Lindström; Erik \& Juha Henriksson (2005) Svengaten, Erik: Erik Lindströmin elämä ja musiikki. Helsinki: Tammi.

Liukko, Vesa (2012) Modaalisen jazzin tulo Suomeen. Tampere University Press: Acta Universitatis Tamperensis.

Lowenthal, David (1998) The Heritage Crusade and the Spoils of History. Cambridge University Press. 
Moisala, Pirkko (2010) "Suomalainen musiikintutkimus ja etnomusikologia". Musiikki, 3-4, pp. $71-82$.

Monson, Ingrid (1994) “Doubleness and Jazz Improvisation: Irony, Parody, and Ethnomusicology". Critical Inquiry. 20:2, pp. 283-313.

Nicholson, Sutart (2005) Is Is Jazz Dead? (or has it moved to a new address. London: Routledge.

Porter, Lewis (1988) "Some Problems in Jazz Research". Black Music Research Journal, 8:2, pp.195-206.

Poutiainen, Ari (2009) Stringprovisation - A Fingering Strategy for Jazz Violin Improvisation. Acta Musicologica Fennica 28. Helsinki: The Finnish Musicological Society.

Poutiainen, Ari \& Kukkonen, Risto (toim.) (2011) Suklaasydän, tinakuoret. Jazziskelmä Suomessa 1956-1963. Helsinki: Jazz \& Pop Arkisto.

Prouty, Kenneth E. (2010) "Toward Jazz's 'Official' History: The Debates and Discourses of Jazz History. Textbooks". Journal of Music History Pedagogy 1:1, pp. 19-43.

Reimann, H. 2011. "Ideology and the cultural study of Soviet Estonian jazz". The Jazz Chameleon. Ed.Janne Mäkelä. The Finnish Jazz \& Pop Archive and International Institute for Popular Culture. Pp. 23-35.

Reimann, Heli (2013) "Jazz Education and the Jazz Periphery: An Example from Estonia". Journal of Music History Pedagogy 3: 2, pp. 183-185.

Toivianen, Mikko (2000) Jazz as the natural system. Phenomenological and semiotic research into the myth of jazz and its meaning. University Library of Jyväskylä.

Tomlinson, Gary (2002) "Cultural Dialogics and Jazz: A White Historian Signifies Author(s)". Black Music Research Journal. 22, pp. 71-105.

Tucker, Mark (1998) "Musicology and the New Jazz Studies". Journal of the American Musicological Society. 51:1, pp. 131-148.

Tucker, Sherry. (2005) “Deconstructing the Jazz Tradition: The 'Subjectless Subject' of New Jazz Studies". The Source: Challenging Jazz Criticism. 2:2, pp 31-45.

Walser, Robert (1995) “Out of Notes: Signification, Interpretation, and the Problem of Miles Davis“. Among the Discourses. Ed. Krin Gabbard. London: Duke University Press. Pp. 165-188. Weisethaunet, Hans (2007) "Historiography and Complexities: why is music national'?" Popular Music History, 2(2), pp. 169-199.

Whyton, Tony (ed.) (2011a) Jazz. Farhnam: Ashgate.

Whyton, Tony (2011b) "Introduction". Jazz. Ed. Tony Whyton. Farhnam: Ashgate. Pp. xi- xxiii. Whyton, Tony (2012) "Europe and the New Jazz Studies". Eurojazzland: jazz and European Sources, Dynamics and Contexts. Eds. Luca Cerchiari \& Laurent Cugny \& Franz Kerschbaumer. Boston: Northeastern University Press. Pp. 366-380. 